\title{
Çözüm Odaklı Kısa Süreli Psikolojik Danışma ve Öyküsel Psikolojik Danışma Yaklaşımlarına Dair Karşılaştırmalı Bir İnceleme
}

\author{
A Comparative Study Regarding Solution-Focused Brief Counseling and Narrative Counseling \\ Approaches
}

\section{Ayșegül ERÇEVIKK[1]}

Postmodernizm ve yapılandırmacılık akımları ve değișen bilim anlayışı psikolojik danışma sürecini de etkilemiştir. Çözüm Odaklı Kısa Süreli Psikolojik Danışma ve Öyküsel Psikolojik Danışma postmodernizmin ve yapılandırmacılığın etkileriyle ortaya çıkan ve yaygın olarak kullanılan yaklaşımlardandır. Her iki yaklaşım danışma sürecinin nesnel olarak yürütülebileceği düşüncesine karşı çıkmaktadır. Psikolojik danışma sürecindeki etkileşim gerçekliği yeniden yapılandırmakta hem danışanda hem de psikolojik danışmanda değişim yaratmaktadır. Her iki yaklaşım danışanın deneyiminin öznel olduğu fikrini benimsemektedir. Bu öznel deneyime ilişkin bilgiye sahip olan kişi ise danışandır ve dolayısıyla hayatının uzmanı kendisidir. Aynı zamanda her danışanın deneyimine ilişkin çözümlerinin de öznel olduğu vurgulanmaktadır. Psikolojik danışman ise iyi bir dinleyici konumundadır. Felsefi temelleri ortak olan bu iki yaklaşım belli noktalarda farklılaşmaktadır. Çözüm odaklı kısa süreli psikolojik danışmada danışanın deneyimini anlamak için sorular aktif olarak kullanılmaktadır. Bu yaklaşımda odak çözümlerdir ve çözüme yönelik adımlar ve sorunu azaltan deneyimler incelenmektedir. Dolayısıyla şimdi ve gelecek odaklı bir yaklaşım olduğu söylenebilir. Çözüm odaklı kısa süreli psikolojik danışmada soruların süreç içerisinde yoğun kullanımı söz konusudur. Öyküsel psikolojik danışmada ise sorunun baskın öyküden kaynaklandığı ifade edilmekte ve derinine araştırılmasına odaklanılmaktadır. Psikolojik danışma sürecinde bu öykülerin yeniden yazılmasına çalışılmaktadır. Bu bakımdan şimdi ve geçmiş odaklı bir inceleme içerdiği söylenebilir. Her iki yaklaşımında psikoterapi uygulamalarına kattığı yeni teknikler bulunmaktadır. Bu çalışmada Çözüm Odaklı Kısa Süreli Psikolojik Danışmanlık ve Öyküsel Psikolojik Danışmanlık yaklaşımlarının temelleri, insana bakışı ve temel varsayımları ve psikolojik danışma süreçleri karşılaştırılmıştır.

Anahtar Kelimeler: çözüm odaklı kısa süreli psikolojik danıșma, öyküsel psikolojik danıșma, postmodernizm, yapılandırmacılık, danışan, psikolojik danışman

Received Date:24 May 2021

Postmodernism and constructivism movements and changings of scientific understanding have effects on psychological counseling processes, too. Solution-Focused Brief Counseling and Narrative Counseling are approaches that emerged with the effects of postmodernism and constructivism and are widely used. Both approaches oppose the idea that the counseling process can be practiced objectively. The interaction between client and psychological counselor in the counseling process reconstructs reality and creates changings in both the client and the psychological counselor. Both approaches accept the idea that the client's experience is subjective. The person who has knowledge of this subjective experience is the client, therefore the expert of his life is the client, too. In addition, it is emphasized that the solutions for each client's experience are subjective. The psychological counselor has a good listener role. These two approaches based on the same the philosophical basis, differ in some points. Solution-Focused Brief Counseling uses questions actively to understand the client's experience. The focus of the approach is solutions and steps towards solutions and experiences that reduce the problem are examined in this approach. Due to these characteristics, it can be said that it is a present and future-oriented approach. There is an intense use of questions in the process of the Solution-Focused Brief Counseling. In Narrative Counseling, on the other hand, it is stated that the problem arises from the dominant story and focuses on in-depth investigation. These problematic stories are being made to rewrite in counseling process. In this respect, it can be said that it includes a present and past oriented analysis. Both approaches have new techniques that they added to psychotherapy practices. In this study, processive perspectives of the Solution-Focused Brief Counseling and Narrative Counseling approaches, their perspectives on people and assumptions, and counseling processes are discussed.

Keywords: solution-focused brief counseling, narrative counseling, postmodernism, constructivism, client, psychological counselor karşılaştırmalı bir inceleme. Humanistic Perspective, 3 (2), 400-419. https://doi.org/10.47793/hp.942378

[1] Dr. Öğr. Görevlisi | Amasya Üniversitesi | Eğitim Fakültesi | RPD | Amasya | Türkiye | ORCID: 0000-0003-3697-458X | aysegulercevik@amasya.edu.tr 


\section{GíRİs}

$\mathrm{P}$ sikoloji biliminde üç dönemin varlığından söz edilmektedir. İlk iki dönem modernizm odaklıdır. Modernizmde bilginin doğası nesnellik üzerine kurulmuş, nicel ve deneysel olarak elde edilen bilgi üzerine odaklanılmaktadır. Bu bağlamda psikolojik danışma yaklaşımlarında öne sürülen varsayımlar tüm insanlar için ortak kabul edilmiş ve bu varsayımlardan hareketle çözüme gidilmiştir. Modernizmi içeren ilk dönemde Psikodinamik yaklaşımlar hakimdir. $\mathrm{Bu}$ yaklaşımlarda patoloji temel odaktır ve patolojinin kökleri aranmaktadır. Freud'la başlayan bu dönem bilişsel psikolojik danışma yaklaşımlarına kadar devam etmiştir. Beck ve Ellis ile başlayan ikinci dönemde de problem temel odak olmaya devam etmiştir ancak "şimdi ve burada" ekseninde ele alınmaya başlanmıştır (Corsini ve Wedding, 2012). Üçüncü dönem ise, postmodernizmi içeren ve bireyin güçlü yönlerini vurgulayan yaklaşımları içermektedir. Bu psikolojik danışma süreçleri deneyimlerin öznelliğine vurgu yapmakta ve bireyi bulunduğu zaman dilimi ve yerellik gibi çevresel öğelerle birlikte ele almaktadır (Arkonaç, 2008; Karaırmak ve Aydın, 2007). Bu perspektif değişimi ile danışanın deneyimlerinin öznelliğini ve yaşamının uzmanının kendisi olduğunu vurgulayan ve psikolojik danışman-danışan ilişkisinde eşitlik sağlayan yaklaşımlar ortaya çıkmıştır. Bu yaklaşımlardan Çözüm Odaklı Kısa Süreli Psikolojik Danışma ve Öyküsel Psikolojik Danışma Türkiye ve Dünya'da son yıllarda yaygın olarak kullanılmaya başlayan yaklaşımlardır.

Çözüm odaklı kısa süreli psikolojik danışmanlık yaklaşımının hem bireysel psikolojik danışmada hem de grupla psikolojik danışma ve psikoeğitim çalışmalarında etkili bir yaklaşım olduğu bildirilmektedir (Kim, 2008). Kısa sürede danışanın amacına erişilmesini sağlayan bu yaklaşım (Doğan, 1999), ergenlerde depresyonu (Javanmiri, Kimiaee Abadi, 2012) ve risk alma davranışını azaltma (Uysal 2014a), travma mağduru çocukların uyku problemlerini azaltma (Lui, 2017), çiftlerde evlilik uyumunu arttırma (Zimmerman, Prest ve Wetzel, 1997) gibi birçok problemde etkili bulunmuştur. Benzer şekilde Öyküsel Psikolojik Danışmanlık da etkili bulunan yaklaşımlardandır. Öyküsel psikolojik danışmaya ilişkin çalışmaların doğası gereği nitel olduğu ifade edilse de (Karaırmak ve Bugay, 2010) nicel çalışmaların da olduğu görülmektedir. Araştırma sonuçları öyküsel psikolojik danışma süreçlerinde ve psikoeğitim çalışmalarında etkili bir şekilde kullanılabildiğini göstermektedir. Öyküsel psikolojik danışmanın aile terapisi uygulamalarında (Besa, 1994), eşleri alkol bağımlılığı sorunu yaşayan kadınları stres düzeyini azaltma ve iyi oluşunu arttırmada (Khodayarifard ve Sohrabpour, 2018), depresyonu azaltmada (Vromans ve Schweitzer, 2011) ve gençlerin kendine zarar verme davranışlarını azaltma (Hannen ve Woods, 2012) gibi birçok problemde etkili bir yaklaşım olduğu görülmektedir.

İki psikolojik danışma yaklaşımı yaşıt olmakla birlikte öyküsel psikolojik danışma Avusturalya ve Yeni Zelanda' dan, çözüm odaklı kısa süreli psikolojik danışma ise; Amerika 
yerelinde yola çıkmış yaklaşımlardır. Farklı kıtaların değișen görüşlerine psikolojik danışma süreçlerine farklı katkıları bulunmaktadır. Danışan ve psikolojik danışmana verilen roller açısından diğer psikolojik danışma yaklaşımlarından farklı bir çizgiye sahip olan bu postmodern ve yapılandırmacı yaklaşımlar; psikolojik danışma sürecine yeni bir soluk getirmesinin yanında, çözüm sürecini hızlandırması ile maddi ve manevi yıpranmayı hızla azaltabilir görünmektedir. Felsefi temeller açısından benzeşen bu yaklaşımların; danışanı ele alışı biçimleri ve psikolojik danışma teknikleri farklılaşmaktadır. Bu çalışmada bu iki psikolojik danışma yaklaşımının felsefi temelleri, psikolojik danışma süreçleri ve teknikler açısından incelenmesi amaçlanmaktadır. Corsini ve Wedding'e göre (2012) psikolojik danışma ve psikoterapi nitelik bakımından aynı görülmekte olduğundan bu çalışmada psikolojik danışma-psikoterapi kavramları aynı anlamda kullanılmıştır.

\section{Çözüm Odaklı Kısa Süreli Psikolojik Danışma ve Öyküsel Psikolojik Danışma Yaklaşımlarının Temelleri}

Çözüm odaklı kısa süreli psikolojik danışma ve öyküsel psikolojik danışma son kırk yılda geliştirilmiş iki yaklaşımdır. Bu iki yaklaşımın ortaya çıkış zamanı yakın olmakla birlikte, bağlamsal farklılıklara sahiptir. İki yaklaşım postmodernizmin söylemleri ve sonrasında yapılandırmacı akımların etkisiyle değișen dünya görüşlerini yansıtan yaklaşımlardır. Elbette bireysel farklılıklar nedeniyle bu akımların yorumlanış biçimleri farklılığa yol açmış; temel hedefi ve uygulama süreleri benzeşen, insana bakışında ve kullandığı tekniklerde farklılaşan iki yöntem doğmuştur.

Geleneksel psikoloji, tarihsel ve felsefi gelişimlerin etkisiyle deneycilik ve akılcılığı ön plana çıkarmıştır. Bunun nedeni olarak psikolojinin bir bilim olmak üzere felsefeden ayrılışı gösterilmektedir. Bilim olmayı sağlama amacıyla psikolojik doğa bilimleri gibi deneyciliği, sebepsonuç ilișkisini ve gözlenebilirliği temele almıștır. Wundt' un ilk psikoloji laboratuvarını kurmasıyla başlayan bu bilim olma iddiası, Wundt' un savunduğunun aksine insana dair her şeyin bilimsel yöntemle keşfini içeren bir düzlemde sürmüştür (Arkonaç, 2008; Karaırmak ve Siviş, 2008). Modernizmde bilginin doğası nesnellik üzerine kurulmuş, nicel ve deneysel olarak elde edilen bilgi üzerine odaklanmıştır. Bu bağlamda psikoterapi yaklaşımlarında öne sürülen varsayımlar tüm insanlar için ortak kabul edilmiş ve bu varsayımlardan hareketle çözüme gidilmiştir. Ancak bu düşünce yirminci yüzyılın sonlarında yerini postmodernizme bırakmaktadır.

Postmodernizm ile bilginin arayışında birden fazla yoruma önem veren öznellik kavramı gündeme gelmeye başlamıştır. Bu felsefi yönelim özellikle sosyal bilimler alanında nesnelliğin yerini öznel bir bakışın almasına neden olmuştur. Modernist düşünce bireyin olumsuz yanlarını 
(ruhsal rahatsızlıklar) ele almaktayken, postmodernist düşünce bireyin olumlu yanlarını (iyi oluş) vurgulayan bir yaklaşımı benimsemektedir (Karaırmak ve Siviş, 2008).

Yirmi birinci yüzyılın başlarında psikoloji alanında var olan ve insan davranışlarını açıklayan kuramların ve kullanılan yöntemlerin birey ve toplumların değişen ihtiyaçlarını karşılayamadığı ve postmodernizmin ötesinde bir üst kurama ihtiyaç duyulduğu belirtilmiştir. Birey odaklı psikolojik danışma yaklaşımlarının, nesnel gerçeklik gibi kavramların yerini giderek sosyal ve kültürel değişimlere duyarlı psikolojik danışma yaklaşımları, nitel yöntemler ve öznel gerçeklik almıştır (Karaırmak ve Aydın, 2007). Yapılandırmacı yaklaşım olarak isimlendirilen bu yaklaşım psikolojik danışmada, danışan ve psikolojik danışman arasındaki ilişkiyi yeniden düzenlemiş ve psikolojik danışmanın müdahaleciliğinin yerini "daha iyi dinleyicilik" almıştır. Yapılandırmacılık danışanın yaşam öykülerini ayrıntılandıran ve onun öznelliğine dayalı bir anlamlandırma yapmaya çalışan ve psikolojik danışma sırasında bu öykülerin yeniden yapılandırıldığını ifade eden bir yaklaşımdır. Buna göre insanlar sunulan bilgiyi basit ve edilgen bir şekilde almak yerine deneyimleri sonucu ortaya çıkan bilginin etkin yaratıcıları olarak kabul edilmektedir (Burr, 2012; Karaırmak ve Aydın, 2007). Dolayısıyla psikolojik danışma sürecinde de bu etkin rolün sürdürülmesine çalışılmaktadır.

\section{“İnsan”a Bakış ve Temel Varsayımlara İlişkin Benzerlikler ve Farklııklar.} Postmodernizmin insana bakışta en önemli getirilerinden biri, insanın eşsiz olduğuna dair düşüncedir. Bu vurgu modern psikolojik danışma yaklaşımlarındaki reçetelere karşı çıkan ve öznelliği vurgulayan bir düşüncedir. Ayrıca insan için yapılacak bir sınıflamanın doğru olmadığı çünkü örneğin kişiliğin sabit kalamayacağını, her yeni yaşantıda farklılaşabileceği ifade edilmektedir. Benzer şekilde farklı ortamlarda da farklı kişilik özellikleri gösterilebileceği vurgulanmaktadır. Bir kişilik özelliğinin dünyanın neresinde olursa olsun tüm insanlarda bulunabilmesi olanaksızdır (Burr, 2012). Öznellik hem Çözüm odaklı kısa süreli psikolojik danışmada hem de öyküsel psikolojik danışmada önemlidir. Ancak iki yaklaşımda bunu farklı bir biçimde ele almaktadır.

Çözüm odaklı kısa süreli psikolojik danışma, bu vurgudan yola çıkarak danışanın öznel yaşantısını ele alır. Ancak bu ele alma sürecinde yaşanılan sorun kategorize edilmek yerine çözüme odaklanılır ve danışanın kendi öznel yaşantısından yola çıkarak istediği/bulduğu çözümler inşa edilir (Tarragona, 2008). Danışan bir problemi yaşamakta ancak sadece o problemden oluşmamaktadır. Danışanın hayatına bu problemin etki etmediği istisnai zamanlar vardır (Corey, 2005; Mole, 2004; Morgan, 2002; Sklare, 2013; Walter ve Peller, 1993) ve problem danışanın dışında (dışsallaştırma) ama danışanı etkileyen bir konumdadır (Legowski ve Brownlee, 2001; Payne, 2006; Russell ve Carey, 2002; Wolter, DiLollo ve Apel, 2006). Çözüm 
odaklı kısa süreli psikolojik danışmada bireylerin öznel yaşantıları olduğu gibi; sorunlarına bulunacak çözümler de özneldir (Sklare, 2013).

Öyküsel psikolojik danışmada da öznellik vurgulanmaktadır. Bireyin öyküsünün öznel olarak ele alınması önemlidir (Murdock, 2013; Payne, 2006; White, 1995). Her bir insan pek çok öyküye/ benliğe sahiptir, her bir kendiliğin ifade edilmesinin de durumlara göre ortaya çlktığı belirtilmektedir (Murdock, 2013). İnsan varlığının en temel özelliğinin onların anlam verme eğilimi olduğu belirtilmektedir. Bu anlamlar doğal olarak özneldir ve danışma sırasında insanın gelişimsel sürecine değil de özgün olarak yaşanan trajik durumlara, kültürel bağlama ve durumla ilgili öznel algıya daha fazla önem vermektedir (Karaırmak ve Bugay, 2010).

Modernist psikolojik danışma yaklaşımlarından farklı olarak danışan (Türkiye'de hala geçerli olan kullanım danışan) hasta ya da danışan olarak nitelendirilmemekte ve müşteri/client olarak anılmaktadır. Modernist psikolojik danışma yaklaşımlarının hasta ve danışan ifadelerinin psikolojik danışma sürecinde hiyerarşiyi vurguladığını ifade etmektedir. Danışan uzman kişi olan psikolojik danışmanın bilinçli tedavisine ihtiyaç duyar (Şahin, 2001). Postmodern psikolojik danışma yaklaşımlarında ise; "cilent is an expert" danışanın kendi hayatının uzmanının kendisi olduğu (Anderson ve Goolishian, 1992; Murdock, 2013; Payne, 2006; Sklare, 2013; White, 1995); psikolojik danışmanın ise "not knowing position" bilmeyen pozisyonunda olduğu belirtilmektedir. Psikolojik danışmanlar durumla ilgili bir şey bilmeyen ve öğrenme için sorular soran kişilerdir (Anderson ve Goolishian, 1992; Tarragona, 2008). Bu doğrultuda çözüm odaklı kısa süreli psikolojik danışmada bireyler yaşamlarının uzmanları olarak görülmekte ve aslında sorunlarını çözebilecek yeteneği ve kaynakları içlerinde barındırdıkları düşünülmektedir. Bireylerin yaşantıları öznel olduğu gibi; sorunlarına bulunacak çözümler de özneldir (Sklare, 2013). Benzer biçimde öyküsel psikolojik danışmada da bireyler yaşamlarının uzmanı olarak görülmektedir (Murdock, 2013; Payne, 2006; White, 1995). Ancak yaşantıların kültürel kalıplarla yorumlanmasıyla; bireylerin öyküleri oluşmaktadır. Yani öyküler insanları, insanlar öyküleri etkileşimli bir şekilde oluşturmaktadır. Çözüm yeni öykülerin oluşturulmasıyla gelmektedir. Yani geçmişten gelen öykü sorun olmaya başladığında, yeni bir öykü yazılabilir (Carey ve Russell, 2003; White, 1995). Tablo 1' de iki psikolojik danıșma yaklaşımının varsayımları sıralanmıştır: 


\section{Tablo 1}

Çözüm Odaklı Kısa Süreli Psikolojik Danışma ve Öyküsel Psikolojik Danışma Yaklaşımlarının Varsayımları

\begin{tabular}{ll}
\hline \multicolumn{1}{c}{ Çözüm Odaklı Kısa Süreli Psikolojik Danışma } & \multicolumn{1}{c}{ Öyküsel Psikolojik Danışma } \\
\hline Danışan çözüme odaklandığında faydalı değişimler de & Danışanlar fenomenolojik dünyalarına ait bireye özgü \\
ardından gelecektir. & yönleri açığa vururken kişisel öykülerini kullanırlar. \\
Her problemin yaşanmadığı anlar -istisnalar- & Psikolojik danışma sürecinde kültürel ve ortak öykülerin \\
bulunmaktadır. Bunlar problemin çözümüne katkı & danışan tarafından anlaşılması terapötik ilişkilerin \\
sağlamaktadır. & temelidir (Gonçalves ve Machado, 1999; akt: Karaırmak ve \\
Küçük değişimler genişleyerek büyük değişimlere yol & Bugay, 2010,s. 27). \\
açar. & Danışanların “probleme doymuş öykü’lerinde istisnai \\
Bütün danışanlar kendi sorunlarını çözebilecek & durumlar bulunmaktadır. İstisnai durumlardan \\
potansiyele sahiptir. & faydalanılarak alternatif öyküler oluşturulabilir. \\
Danışanın amaçları neleri yapmak istemediğini içeren & Problem danışanla bütünleşmiş değildir, bu nedenle \\
olumsuz cümleler yerine (kaygılı olmak istemiyorum), & danışandan ayrı olarak ifade edilmelidir (Corey, 2005; \\
neleri yapmak istediğini yansıtan olumlu cümlelerle & Payne, 2006). \\
ifade edilmelidir. & \\
Danışma sürecinde işe yarayan şeyler daha fazla & \\
yapılmalı, işe yaramayan uygulamalar & \\
tekrarlanmamalıdır (Corey, 2005; Sklare, 2013; Uysal, & \\
2014b, Walter ve Peller, 1993). & \\
\hline
\end{tabular}

Çözüm odaklı kısa süreli psikolojik danışmada psikolojik danışma sürecine danışanı getiren problem üzerinde durmaktansa çözüme odaklanıldığı görülmektedir. Danışanın problem olarak getirmediği bir durum "bozulmayanı tamir etmeme" anlayışıyla ele alınmamaktadır. Ayrıca "işe yarayan çözümleri sürdürme" de danışanın problemle ilgili bazı adımları atabildiğine dair düşünceyi ifade etmekte ve danışana güç vermektedir (De Shazer, Dolan, Korman, Trepper, McCollum ve Berg, 2007).

Öyküsel psikolojik danışmada ise danışanların "probleme doymuş öyküleri" ele alınmakta yani soruna ilişkin bilgiye odaklanılmaktadır. Bu öykünün danışanın perspektifinden anlaşılması oldukça önemlidir. Sorunun anlaşılma sürecinde dişsallaştırma tekniği ile sorunun danışan üzerindeki etkilerine ve hangi zamanlarda onu daha fazla rahatsız ettiğine ilişkin bilgiler alınır (Carey ve Russell, 2003; White, 1995). Anlaşıldığı üzere; çözüm odaklı kısa süreli psikolojik danışmada bir çözüm dili hakim iken; öyküsel psikolojik danışmada sorunun derinine incelemesine özellikle yer verilmektedir. Çözüm odaklı kısa süreli psikolojik danışmada çözüme doğrudan ulaşmaya odaklanılırken (De Shazer ve diğ., 2007), öyküsel psikolojik danışmada öyküler sorunun kaynağı olarak alınır ve bu öykünün iyice anlaşılmasından sonra sorunun baskın öyküden kaynaklandığına odaklanılır ve alternatif hikayeler yoluyla çözüme gidilir (Carey ve Russell, 2003; White, 1995). 


\section{Çözüm Odaklı Kısa Süreli Psikolojik Danışmanlık ve Öyküsel Psikolojik Danışmanlıkta Psikolojik Danışma Süreci}

Postmodern yaklaşımlar olarak ele alınan bu iki psikolojik danışma yaklaşımı, psikolojik danışma süreci açısından oldukça farklıdır. Daha önce de belirtildiği gibi çözüm odaklı kısa süreli psikolojik danışmada; psikolojik danışma sürecine konu olan sorun ilgili alınan geçmişe dair bilgi yerine, şimdi ve burada ve geleceğe dair hedefler önemlidir. Öyküsel psikolojik danışmada ise; kişinin hayatında birçok öyküsü bulunduğu ve bu öykülerden birkaçının baskın olduğu ifade edilmektedir. Baskın öyküler genelde psikolojik danışmaya gelmenin nedenidir. Bu baskın öyküler geçmiş yaşantılardan kaynaklanmaktadır. Bu nedenle psikolojik danışmada önce geçmișe, sonra șimdiye odaklanma söz konusudur.

Psikolojik danışmanın ilk oturumunda psikolojik danışman ve danışan tanışırlar. İki yaklaşımda da sorun detaylıca dinlenir; ancak çözüm odaklı kısa süreli psikolojik danışmada danışanın bu psikolojik danışma sonrasında ortaya çıkmasını istediği sonuçlarla ilgili konuşmaya gayret edilir. Psikolojik danışma sürecinin başlangıcındaki anahtar sorular şunlardır (Macdonald, 2007):

- Kendinizi tanitın

- Burada neyi aşmayı düşünüyorsunuz?

- Ne kadar sıklıkla bu problemi yaşıyorsunuz?

- Ne kadar süredir devam ediyor?

- Harekete geçmeye karar verdiğinizden beri daha iyiye ya da kötüye bir değişim oldu mu?

Çözüm odaklı psikolojik danışmada öncelikle problemin detaylı tanımlanmasına yarayan sorular kullanılır. Daha sonra danışanın geçmişten çok geleceğe, sorundan çok çözüme odaklanması sağlanmayı amaçlayan sorularla devam edilir. İlk oturumdan itibaren derecelendirme soruları, mucize soru gibi tekniklerle bulunulan durumun netleştirilmesi ve hedeflenen amacın açık bir biçimde ortaya koyulmasına çalışılır (De Shazer ve Berg, 1997).

İlk oturumda danışan birçok probleminin olduğunu ve nereden başlayacağını bilmediğini ifade edebilir. Ancak çözüm odaklı psikolojik danışmada aynı zamanda yalnızca bir problemle çalışmak önemlidir (Macdonald, 2007). Bundan sonra süreç derecenin arttırılması için önce küçük sonra büyük adımlar atılmasına odaklanma ve bunun için çözümler üretme şeklinde sürer. Psikolojik danışma süreci danışan hedeflediği sonuca ulaştığında sonlandırılır. Çünkü hayatının uzmanı yine danışanın kendisidir. 
Tablo 2

Sorunun ve Çözümün Derecelendirilmesi

\begin{tabular}{ccl}
\hline Puan & Derecelendirme & Ne keşfediliyor? \\
\hline 10 & Mükemmel çözüm & Yaratıcı düşünmeyi teşvik etmek için bir araç olarak mucize soru \\
7 & İyi ama gerçekçi bir çözüm & $\begin{array}{l}\text { Danışanın hayatına problemin müdahalesinin azalması ile ilgili alınan gerçekçi } \\
\text { bir tanımlama. Daha somut ve geç̧ekci olarak en iyi durum. Yaşamın sıradan } \\
\text { yönleriyle birlikte yeterinde iyi bir yaşam kurma. } \\
\text { Danışanın yaptığı her şey bu noktaya (3) ulaşmasına yardım ediyor ya da daha } \\
\text { da kötüleşmeyi önlemek için yaptığı her şey onu bu noktaya getiriyor. }\end{array}$ \\
3 & Danışanın bulunduğu yer & En iyisi ayrıntıya girmemek \\
\hline
\end{tabular}

Iveson (2002)' dan alınmıștır.

Tablo 2'de çözüm odaklı kısa süreli psikolojik danışma sürecinin bir özeti görülebilir. Derecelendirme soruları üzerine Iveson (2002) tarafından verilen bu örnekte, psikolojik danışma sürecinde yapılan uygulamalar özetlenmektedir. Öncelikle danışanın sorunu tüm yönleriyle dinlenmekte, daha sonra mucize soruyla çözülebileceği hissi yaratılmaktadır. Daha sonra derecelendirme sorusuyla nerede olduğu ve problemin hangi düzeyde katlanılabilir olduğu konusunda konuşulmaktadır. Hedefler bir anda çok büyük bir değişim beklentisiyle oluşturulmadan, küçük adımlarla başlar. Ancak küçük adımlar, birleşerek büyük bir adıma; 3’ ten 7’ye yükselmeyi sağlayabilir.

Öyküsel psikolojik danışmada da benzer şekilde sorun derinlemesine irdelenir. Sorun dinlenirken sorulan sorularla aslında baskın olan öykünün temeline inilmeye çalışılır. Ancak problemin bu sorgulama sürecinde danışandan ayrı tutulmasına dikkat edilir:

- Bu kendinden "nefret etme" sana ne söylüyor?

- Senin hayatında ne gibi sorunlara yol açıyor? (White, 2001)

- Bu problem senin motivasyonunu nasil etkiliyor? (Morgan, 2002)

- Kuruntu senin duygularını nasıl etkiliyor? (Morgan, 2002).

$\mathrm{Bu}$ dışsallaştırma sorularıyla danışanın kendisini problemden ayırması amaçlanır ve süreç boyunca hem psikolojik danışmanın hem de danışanın sorunu dışsallaştırılmış biçimde ifade etmesi amaçlanır. Dışsallaştırma sürecinde metaforlardan da yararlanılır. Yani sorun "altına kaçırma" yerine sinsi kaka adını alır (Legowski ve Brownlee, 2001, Mole, 2004). Böylece problem üzerinde konuşmak daha kolay olmaktadır (Wolter, DiLollo ve Apel, 2006). Daha sonra dışsallaştırılan problem üzerinde yapılan konuşmalarda, bu problemin danışanın hayatını etkilemediği eşsiz zamanlar aranır. Bu zamanlar problemin etkisinin en az hissedildiği 
zamanlardır. $\mathrm{Bu}$ zamanlardaki durumlara odaklanarak, danışanın öyküsünün sadece probleminden ibaret olmadığına dair görüş desteklenir (Mole, 2004; Morgan, 2002).

Bir kere problem dışsallaştırıldığında, yeniden yazma süreci başlayabilir (Morgan, 2002). Bu süreç psikolojik danışmanın ikinci adımını oluşturmaktadır ve dışsallaştırma konuşmalarıyla problem bireyin dışında bir kimlik kazandıktan sonra danışan problemin yaşamına etki ettiği her yönü detaylı olarak tanımlayabilir hale gelmektedir (Wolter, DiLollo ve Apel, 2006). Kişinin problemli baskın hikayesi yerine yeniden yazma yoluyla alternatif hikayeler oluşturulur. Alternatif hikayelerde danışanın beklentilerine ve problemin etkisinin en zayıf olduğu eşsiz sonuçlara yer verilir (Carey ve Russell, 2003; White, 1995). Psikolojik danıșman ve danıșan tarafından oluşturulan alternatif hikayelerden seçilen, danışan için en uygun olduğu düşünülen hikâye ile baskın hikaye arasında karşılaştırmalar yapar ve problemin seçilmiş hikayede zayıf olduğu anlar tespit edilerek, danışanın problemin çözülebileceğine dair inancı arttırılır (Carey ve Russell 2003; Mole, 2004).

Öyküsel psikolojik danışma sürecinde teknik olarak hayat kulübü, dış şahitlik ve tanımsal seremoni gibi metaforik uygulamalar yanında mektuplar, ses ve video kayıtları gibi bazı terapötik dokümanlara da yer verilmektedir. Hayat kulübü; Michael White'ın (1997, akt: Russell ve Carey, 2002) insanların hayatlarını, içerisinde farklı rütbe ve statülerde üyelerin bulunduğu bir kulübe benzetmesinden doğan bir kavramdır. Hayat kulübünde danışan üyelerinin statü/rütbelerini düşürebilir ya da yükseltebilir, hayat kulübünü istediği gibi düzenleyen danışan kişileri istediği șekilde konumlandırarak hayatına yön verir (Russell ve Carey, 2002).

Dış şahitlik ve tanımsal seremoni ise; psikolojik danışma sürecine danışanın çevresinden (aile, arkadaş v.b.) bir kişinin ya da bir uzmanın katılmasıdır (White, 1995). Bu uygulama danışana kendi öyküsüne dışardan bakma firsatı verir ve farklı bakış açılarını görmesine olanak sağlamaktadır. Yazılı malzemeler danışanların başarılarını kutlamak ya da pekiştirmek için çoğunlukla yazılı malzemeler kullanırlar. Çünkü yazılanların söylenenlerden daha kalıcı ve güçlü olduğu, danışanın gelişimine önemli kanıtlar sunmaktadır (Murdock, 2013).

Çözüm Odaklı Kısa Süreli Psikolojik Danışma ve Öyküsel Psikolojik Danışma Süreçlerinde Soruların Kullanımı. Psikolojik danışma sürecinde hangi yaklaşım benimsenirse benimsensin; öncelikle sorunun ve amaçların tanımlanması için soru sorma yöntemi işe koşulmaktadır. Soru sorma süreci ister açık uçlu ister kapalı uçlu olsun ortak olarak kullanılan yöntemdir. Sorular tüm yaklaşımlarda kullanılan ve psikolojik danışman-danışan iletişimin önemli bir öğesidir. Danışanın hikayesini alırken, seansın başında danışanın mevcut durumunu kontrol etmek için ya da ev ödevlerinin nasıl bir etkisi olduğunu kontrol etmek için kullanılmaktadır (De Shazer ve diğ. 2007). Modernist sorular uzman konumundaki psikolojik danışmanın benimsediği teoriye dayalı olarak davranışı anlamaya ve açıklamaya hizmet 
etmektedir. Postmodernizmde ise soru sorma, danışanının ve davranışın analizi yerine danışanın deneyimini ve ihtiyaçlarını daha iyi anlamaya hizmet eder (Anderson ve Goolishian, 1992). Hem çözüm odaklı kısa süreli psikolojik danışmada hem de öyküsel psikolojik danışmada sorular belirtilen danışanın deneyimini daha iyi anlayabilmek ve çözüm adımlarını tespit edebilmek adına sorular önemli araçlardır.

Öyküsel psikolojik danışmada soru sorma nedeni olarak danışanın hayatının uzmanın kendisi olduğu ve danışmanın da soru sorma yoluyla danışanın hayatını öğrenmeye çalışan kişi oluşu gösterilmektedir (Corey, 2005; Karairmak ve Bugay, 2010; Morgan, 2002; White, 1995). Danışanın paylaşmak istediği öyküsünün şimdi ya da geçmişte yaşanmış olmasının önemi olmaksızın; sorunu ayrıntılarıyla dinlemeye, danışanın aynı duyguları tekrar yaşayabilmesine ve sonunda bu öyküden alınan bilgilerle tanımlanan sorunun danışanla incelenmesine başlanmaktadır (Payne, 2006). Bu süreç dışsallaştırma konuşmaları olarak anılmakta ve psikolojik danışma sürecinin ilk basamağını oluşturmaktadır (Wolter, DiLollo ve Apel, 2006). Bu basamakta psikolojik danışman, danışanın öyküsünü dikkatlice dinleyerek, ona bunun hakkında birçok soru sorarak, yaşanılan problemin danışana ve danışanın çevresindeki bireylere (aile, arkadaş) etkisi bakımından değerlendirilmesini içermektedir. Böylece problemin bireyin kendi dışında "bir şey" olarak yeniden biçimlendirilmesi sağlanmaya çalışılmaktadır (Murdock, 2013).

\section{Tablo 3}

Dışsallaştırma Örneği

\begin{tabular}{ll}
\hline İçselleştirilmiş durum & Dişsallaştırma soruları/ dişsallaştırılmış durum \\
\hline Kuruntuluyum & Kuruntu senin duygularını nasıl etkiliyor? \\
& Bu Kuruntu sana ne söylüyor? \\
O başarısız & Bu problem onun motivasyonunu nasıl etkiliyor? \\
\hline
\end{tabular}

Morgan (2002, s. 89)'dan düzenlenmiştir.

Öyküsel psikolojik danışma uygulamalarında karşılaşılan problemin dışsallaştırılması için geliştirilen çok bilinen isimler bulunmaktadır. Bunlar "sinsi kaka", "korku avlamak ve canavar evcilleștirmek", "kral kaplan ve kükreyen mide" ve "kaşıntılı parmaklar" dır (akt: Legowski ve Brownlee, 2001). Bu isimlendirmeler problemin derin olarak incelenmesini sağlamaktadır. İnsanların yaşamında problemlerin etkileri, problemlerin nasıl çalıştığını/işlediğini, nasıl hileleri olduğunu, nassl konuştuklarını ve ne gibi görünebildikleri hakkında konuşabilmek için problemlerin dışsallaştırılması önemlidir (Morgan, 2002). Psikolojik danışma sürecinin diğer basamaklarında da danışanın alternatif hikayelerinin oluşturulması, bu hikayelerin değerlendirilmesi ve çeşitli terapötik uygulamalar içinde danışman için öğrenme süreci devam etmektedir. 
Çözüm odaklı kısa süreli psikolojik danışmada sorular temel bir iletişim aracıdır (De Shazer ve diğ., 2007). Danışan deneyimlerinin öznelliği önemli olduğu için deneyimi anlamak için sorular önemlidir. Sorular "şu anda" yaşanan problemin öncelikle tanımlanmasında önemli bir yere sahiptir. Bunun yanında çözümlerin adım adım belirlenmesinde de sık sık kullanılmaktadır. Sorular çözüm odaklı kısa süreli psikolojik danışmanın önemli teknikleri arasındadır. Bu teknikler; mucize soru, istisnai durum soruları, kabus soru, derecelendirme soruları ve başa çıkma sorularıdır (Sarıçam, 2014; Sklare, 2013). Örneğin; mucize soru çözüm odaklı kısa süreli psikolojik danışma yaklaşımının en önemli tekniklerindendir. Mucize soru istenilen geleceğin betimlenerek yaşatılmasını ve problem ortadan kalktığında oluşacak değişimlerin incelenmesini içerir. Problemin çözülebileceğine dair cesareti arttırıcı bir etkiye sahiptir. Ayrıca psikolojik danışmadaki ana amacın oluşturulması için işlevsel bir yol olarak ifade edilmektedir (Macdonald, 2007).

\section{Tablo 4}

\section{Mucize Soru}

Şimdi sana ilginç bir soru soracağım

Varsayalım ki (durun)

Bu gece genelde olduğu gibi yatağa gidiyorsun ve uykuya dalıyorsun (durun)

Ve sen uyurken bir mucize gerçekleşiyor (durun)

Bugün seni buraya getiren problem çözülüyor (durun)

Ama sen uyuyorsun ve problemin çözüldüğünü anlamıyorsun (durun)

Bu mucizenin gerçekleștiğine ve problemin çözüldügüne dair ilk küçük işaret ne olurdu?

Macdonald (2007, s. 19)' dan alınmıştır.

$\mathrm{Bu}$ teknik danışanın istediği geleceği hayal etmesini, kendi iç dinamiklerinin farkına varmasını, çözüme ya da probleme devam etmeyi sağlayacak çevredeki kişileri fark etmesini sağlar (Corey, 2005; Demirci, 2014; Sklare, 2013). Mucize sorulara benzer șekilde kullanılan sihirli küre ve kabus soru de bulunmaktadır (Doğan, 1999; Sarıçam, 2014).

Çözüm odaklı kısa süreli psikolojik danışmada danışan adı depresyon, anksiyete ya da ne olursa olsun bir problem yaşayabilir ancak aynı zamanda bir anne, baba ve çalışan olarak yaşamını sürdürür. Yani danışan mevcut probleminden fazlasını ifade etmektedir (Hanton, 2011). Danışan ilgili sorunu deneyimlemekte ancak bazı istisnai zamanlarda sorunun etkilerini daha az hissetmektedir (Macdonald, 2007). Küçük bir an olsa dahi problemin danışanın yaşamını etkilemediği ya da daha az etkilediği istisnai zamanlara ilişkin sorularla değerlendirilmektedir (De Shazer ve diğ.,2007). Böylece danışan dışsallaştırmada olduğu gibi probleminden zaman zaman ayrışabildiği anları fark etmektedir.

Danıșanın probleminin derecelendirilmesini içeren derecelendirme soruları da sık kullanılan tekniklerdendir. Genel anlamda sorunun en yoğun hali 0 iken sorunun çözülmüş hali 10 puan olarak anılır (Murdock, 2013). Derecelendirme soruları ile ilgili sorunun psikolojik 
danışma randevusu öncesi ile ilk randevu arasında hangi derecede olduğu, şimdi nerede olduğu veya mucize gerçekleştiğinde nerede olacağına bilgileri alırken kullanılmaktadır. Derecelendirme 0-10 ya da 1-10 arasında gerçekleştirilebilmektedir. Danışandan bu derecelendirme cetvelinde şu an hangi sayıda olduğunu ifade etmesi istenir. Sonrasında danışanın verdiği sayıya ilişkin değerlendirme yapması istenir. Danışanın ifade ettiği derece ile (örneğin 2) diğer dereceler arasındaki fark incelenir. "2 ile 3.5 veya 1 arasındaki fark nedir?" (De Shazer ve diğ., 2007). Bunun yanında derecelendirmeler danışanın hedeflerinin belirlenmesinde de kullanılmaktadır. Danışanın ifade ettiği dereceden (örneğin 2) hedefine ulaşması için (örneğin 8) küçük adımlar şeklinde hedefler konulur. Bu amaçla danışana "2.2 ya da 2.5 olmak için atabileceğin en küçük adım ne olurdu?" diyerek küçük adımlar şeklinde hedefine ulaşması sağlanmaya çalışılır. Adımları danışan belirleyeceği için adımlar onun kendi çözüm adımlarını belirlemesi ve böylece kendisine uygun çözümler belirlemesi sağlanmıș olur. Sonraki seanslarda da derecelendirme soruları ile danışanın ilerlemeleri takip edilir ve yeni hedefler belirlemek üzere tekrar işe koşulur (Sklare, 2013).

Başa çıkma soruları, çözümler üzerine konuşmak üzere kullanılmaktadır. Danışanın güçlü yanlarını tespit etme, süreç içerisinde işe yarayan ya da yaramayan tekniklerin değerlendirilmesi önemlidir. "Şimdiye kadar neyi yararlı buldun?" (Dejong ve Berg, 1998; akt: Sarıçam, 2014) gibi bir soruyla danışanın daha önceki başarılı başa çıkma yöntemlerini hatırlaması ve mevcut problemin üstesinden gelmede bu yöntemlerin işe koşulmasını sağlamak hedeflenmektedir. Özetle çözüm odaklı psikolojik danışma sürecinde sorulan sorular Tablo 5' te gösterilmiștir:

\section{Tablo 5}

\section{Çözüm Odaklı Kısa Süreli Psikolojik Danışmada Sorular}

Başa çıkma soruları

Her şeyi denedikten sonra vazgeçmeni nasıl engelledin?

Bugüne kadar başa çıkmayı nasıl başardın?

Seni orada tutan neydi?

Yaşamında iyi giden şeyler neler?

Çözümleri arama

Bir şeyler değiştiğinde fark edeceğin küçük değişim ne olacak?

Bizim konuşmamız büyük bir değişim yaratsaydı nasıl fark ederdin?

Bu hafta senin için daha iyi olan şey neydi?

Bu probleme sahip olmadığın, hatta biraz bile olduğu zamanlar ne zamandı?

İlerleme

Okulu kırmak yerine ne yapıyor olacaksın?

Artık depresyonda olmadığının küçük bir işareti ne olacak?

Kendinizde neye dikkat ediyor olacaksınız? Diğerleri sizinle ilgili hangi farklılığa dikkat edecek?

Bu hafta daha fazla ne yapabilirsin?

Kelly, Kim ve Franklin (2008, s. 17)' den alınmıştır.

Soru sorma tüm danışmanlık yaklaşımlarında psikolojik danışma sürecinin ilk oturumundan son oturumuna kadar sürdürülen önemli bir tekniktir. Ancak soru sorma biçimleri 
psikolojik danışmanın benimsediği yaklaşımdan etkilenmektedir. Öyküsel psikolojik danışmada, öykünün ortaya çıkarılması sırasında ve yeni öykülerin yazılma aşamasında özne değişime uğramakta problem kişiselleştirilerek ifade edilmekte ve bir özne görevi üstlenmektedir. Çözüm Odaklı Kısa Süreli psikolojik danışmada ise problemin tespitine yönelik bir dizi sorudan sonra çözümleri içeren bir dizi tekniği içeren sorular bulunmaktadır. Her psikolojik danışmada olduğu gibi probleme çözüm aranması en önemli amaçken, izlenen yollar değişmektedir.

\section{SONUÇ}

Postmodern ve yapılandırmacı akımlar psikolojik danışma süreçlerinde danışanın nesnel bilgiler ışığında değerlendirilmesine karşı çıkarak, mutlak bir değişmezliğin olamayacağını savunmaktadır. Danışanın deneyimleri özneldir ve psikolojik danışman ve danışan mevcut terapötik ilişkide aynı kalmamakta, kurdukları iletişimle birlikte her iki zihinde de yeni bilgiler yapılanmaktadır (Burr, 2012; Karaırmak ve Aydın, 2007). Oluşan diğer bir farklılık ise, danışanın işlevsiz yönünün olduğu ve danışmanın uzman rolü ile danışanın iyileștirilmesinde aldığı görevdir (Arkonaç, 2008). Ancak postmodernizmle birlikte danışan yalnızca problem deneyimleyen bir birey olmak dışında da yaşamını sürdürebilen ve kendi çözümlerini oluşturabilen bir birey olarak ele alınmaktadır (Corey, 2005; Mole, 2004; Morgan, 2002). Bunun yanında ilgili deneyimi veya öyküyü en iyi bilen kişi danışanın kendisidir, danışan kendi hayatının uzmanıdır ve psikolojik danışman "bilmeme" konumunda sorular soran kişidir (Anderson ve Goolishian, 1992; Tarragona, 2008). Psikolojik danışmanın uzman olduğu bakışından uzmanın danışan olduğu bakışına doğru gerçekleșen bu değişimin psikolojik danışma sürecine yansımalarında bu çalışmanın da konusu olan çözüm odaklı kısa süreli psikolojik danışma ve Öyküsel psikolojik danışma yaklaşımlarını karşımıza çıkmaktadır.

Hem çözüm odaklı psikolojik danışma hem de öyküsel psikolojik danışma postmodernizm ve yapılandırmacılık akımlarının nesnellikten öznelliğe geçiş, danışanın güçlü yönlerini vurgulama, danışanın yaşamının uzmanı olması ve psikolojik danışmanın iyi bir dinleyici rolü gibi getirilerini barındırmaktadırlar. Psikolojik danışma sürecindeki bu değişimi iki yaklaşımın da ortak katkıları arasındadır (Anderson ve Goolishian, 1992; De Shazer ve diğ.,2007; White, 1995).

Hem çözüm odaklı kısa süreli psikolojik danışmada hem de öyküsel psikolojik danışmada danışanın deneyiminin bir tanı olarak değerlendirilmediği, problem ne kadar yoğun olursa olsun etkisinin azalıp arttığı zamanların olabileceğine ilişkin fikir ortaktır. Bu durum her iki yaklaşımda da problemin deneyimlenmediği istisnai zamanlar araștırılarak, problemin ne zaman çok ne zaman daha az etkilediği sorularak (dışsallaştırma) tespit edilmeye çalışılmaktadır (Murdock, 2013; Tarragona, 2008). Bu yolla problem danışanla bütünleștirilmek yerine ayrıştırılmaktadır. Bu fikrin diğer bir katkısı da problemini azaltmak için sahip olduğu bir güç 
olduğunu vurgulamak ya da öyküyü değiștirebileceğine dair gücünün olduğunu ifade etmektir. Her iki yaklaşım da danışanın gücünü vurgulamaktadır (Casey ve Russell, 2003; Sklare, 2013; Walter ve Peller, 1993; White, 1995).

Modern psikoterapi yaklaşımları danışanı hasta ya da danışan olarak adlandırmaktadır (Corsini ve Wedding, 2012). Türkiye'de danışan terimi hala kullanılmaya devam etmesine rağmen çözüm odaklı kısa süreli psikolojik danışma ve Öyküsel psikolojik danışma yaklaşımları danışan ve psikolojik danışman ilişkisini eşit bir pozisyona alan müşteri/client terimini tercih etmektedir. $\mathrm{Bu}$ şekilde psikolojik danışmanın uzman konumu yerini eşit bir ilişkiye bırakmaktadır (Anderson ve Goolishian, 1992; Tarragona, 2008).

Çözüm odaklı kısa süreli psikolojik danışma ve öyküsel psikolojik danışma yaklaşımlarının etkililiklerin hem nitel hem de nicel yöntemle sınandığı, birçok olumsuz deneyimde anlamlı olumlu değişimlerin olduğu belirtilmektedir (Besa, 1994; Forcht ve Beardslee, 1996; Javanmiri, Kimiaee Abadi, 2012; Zimmerman, Jacobsen, MacIntyre ve Watson, 1996). Bu açıdan her iki yaklaşım da psikoterapi süreçlerinde etkili bulunmaktadır.

İki yaklaşım da diğer yaklaşımlardan farklı, özgün yönlere sahiptir. Özellikle danışan ve psikolojik danışman ilişkisinde danışanın hayatının uzmanı oluşu, onun fenomenlerinin ve çözümlerinin önemli oluşunun çözüme önemli bir katkısı olduğu düşünülmektedir. Çözüm odaklı kısa süreli psikolojik danışma yaklaşımı, maliyeti minimuma indiren ve hızla çözüme giden bir yaklaşımdır. Pek çok teknikle direnci kırması, çözüme odaklanmayı kolaylaştırması özgün yönlerindendir (Corey, 2005; Demirci, 2014). Ayrıca danışanın güçlü yönlerinden başlayarak çözüme gittiği, yani danışana en baştan "Sen başarabilirsin" mesajını verdiği düşünülmektedir. Öyküsel psikolojik danışma özellikle dışsallaştırma konuşmalarının farklı ve faydalı bir yöntem olduğu düșünülmektedir. Dıșsallaștırmada kullanılan metaforlar danıșanın sorunuyla ilgili rahatça konuşabilmesini, soruna değil de çözüme odaklanmasını kolaylaştırıcıdır (Wolter, DiLollo ve Apel, 2006). Bununla birlikte hayat kulübü uygulamasının, danışanın hayatının kendi iradesinde olduğu fikrini pekiștirici olduğu düşünülmektedir. Dış şahitlik ve tanımsal seremoni uygulaması da benzer şekilde danışan için zihin açıcı bir uygulama olarak değerlendirilebilir.

Çözüm odaklı kısa süreli psikolojik danıșma daha hızlı yaygınlaşmış ve pek çok araştırmaya konu olmuştur (Kim, 2008). Türkiye'de özellikle okullarda kullanım açısından işlevsel olduğu ifade edilmektedir (Meydan, 2013). Öyküsel psikolojik danışma, Dünya'da yaygın ancak Türkiye'de yeni yeni tanınan bir yaklaşımdır (Karaırmak ve Bugay, 2010). Bununla birlikte son yıllarda tanınırlığının artmasına yönelik çalışmaların giderek arttığını söylemek mümkündür (Çelik, 2017; Dinç ve Dinçer, 2020). 


\section{KAYNAKÇA}

Anderson, H., \& Goolishian, H. (1992). The client is the expert: A not-knowing approach to therapy, içinde Therapy as social construction, S. McNamee ve K.J. Gergen (Ed.). Sage Publications Ltd.

Arkonaç, S. A. (2008). Psikolojide insan modelleri ve yerel insan modelimiz (2. Baskı). Nobel Yayın Dağıtım.

Besa, D. (1994). Evaluating narrative family therapy using single-system research designs. Research on Social Work Practice, 4(3), 309-325.

Burr, V. (2012). Sosyal inşacılık (Çev. S. A. Arkonaç). Ankara: Nobel Yayın Dağıtım.

Carey, M., \& Russell, S. (2003). Outsider-witness practices: Some answers to commonly asked questions. International Journal of Narrative Therapy \& Community Work, 3(1), 1-22.

Corey, G. (2005). Psikolojik danışma psikoterapi kuram ve uygulamaları (çev. T. Ergene). Mentis Yayıncılık.

Corsini, R.J., \& Wedding, D. (2012) Modern psikoterapi teknikleri (Çev. E. Güzelyazıcı, S. DarcanÇiftçi ve M. Türkoğlu). İstanbul: Kaknüs Yayınları.

Creswell, J.W. (2013). Nitel araștırma yöntemleri: Beş yaklaşıma gire nitel araștırma ve nitel araştırma deseni (çev. Ed. M. Bütün, S.B. Demir). Siyasal kitabevi.

Çelik, H. (2017). Psikoterapide yeni soluk: Öyküsel terapi. E-Kafkas Eğitim Araştırmaları Dergisi, 4(1), 34-50.

Çitemel, N. (2014). Çözüm odaklı kısa süreli grupla psikolojik danışmanın lise öğrencilerinin akran zorbalığına etkisi [Yayımlanmamış doktora tezi]. Sakarya Üniversitesi.

De Shazer, S., \& Berg, I. K. (1997). 'What works?'Remarks on research aspects of solutionfocused brief therapy. Journal of Family Therapy, 19(2), 121-124. https://doi.org/10.1111/1467-6427.00043

De Shazer, S., Dolan, Y., Korman, H., Trepper, T., McCollum, E., \& Berg, İ.K. (2007). More than miracles: The state of the art of solution-focused brief therapy. Routledge.

Demirci, İ. (2014). Çözüm odaklı kısa terapi. İçinde A. N. Canel (ed), Terapide yeni ufuklar: Modern, postmodern ve kısa terapiler II (s. 171-200). Pinhan Yayıncllık.

Dinç, M. ve Dinçer, E.M. (2020). Narrative terapi uygulamaları: Türkiye'de yürütülen bireysel ve toplu çalışmalar. Ketebe Yayınları.

Doğan, S. (1999). Çözüm-Odaklı Kısa Süreli Terapi: Kuramsal Bir İnceleme. Türk Psikolojik Danışma ve Rehberlik Dergisi, 2(12), 28-38.

Franklin, C., Moore, K., \& Hopson, L. (2008). Effectiveness of solution-focused brief therapy in a school setting. Children \& Schools, 30

$15-26$. https://doi.org/10.1177/104973150101100401 
Focht, L., \& Beardslee, W. R. (1996). "Speech after long silence": The use of narrative therapy in a preventive intervention for children of parents with affective disorder. Family Process, 35(4), 407-422. https://doi.org/10.1111/j.1545-5300.1996.00407.x

Hannen, E., \& Woods, K. (2012). Narrative therapy with an adolescent who self-cuts: A case example. Educational Psychology in Practice: Theory, Research and Practice in Educational Psychology, 28(2), 187-214. https://doi.org/10.1080/02667363.2012.669362

Hanton, P. (2011). Skills in solution focused brief: Counselling \& psychotherapy. Sage. http://dx.doi.org/10.4135/9781446251980

Iveson, C. (2002). Solution-focused brief therapy. Advances in Psychiatric Treatment, 8(2), 149156. https://doi.org/10.1192/apt.8.2.149

İlbay, A. B. (2014). Çözüm odaklı kısa süreli grupla psikolojik danışmanın üniversite öğrencilerinin tükenmişlik düzeyleri üzerindeki etkisi [Yayımlanmamıș doktora tezi]. Sakarya Üniversitesi.

Javanmiri, L., Kimiaee,S.A., \& Abadi, B.A.G.H.(2013). The study of solution-focused group counseling in decreasing depression among teenage girls. International Journal of Psycholojical Studies, 5(1), 105-111. http://dx.doi.org/10.5539/ijps.v5n1p105

Karaırmak, Ö., \& Aydın, G. (2007). Yapılandırmacı yaklaşım: Çağdaş psikolojik danışma anlayışını ve uygulamalarını biçimlendiren bir güç. Türk Psikolojik Danışma ve Rehberlik Dergisi, 3(27), 91-108.

Karaırmak, Ö., \& Bugay, A. (2010). Postmodern diyalog: Öyküsel psikolojik danışma. Türk Psikolojik Danışma ve Rehberlik Dergisi, 4(33), 24-36.

Karaırmak, Ö., \& Siviş, R. (2008). Modernizmden postmodernizme geçiş ve pozitif psikoloji. Türk Psikolojik Danışma ve Rehberlik Dergisi, 2(30), 102-115.

Kelly, M. S., Kim, J. S., \& Franklin, C. (2008). Solution-focused brief therapy in schools: A 360degree view of research and practice. Oxford University Press Oxford workshop series.

Khodayarifard, M., \& Sohrabpour, G. (2018). Effectiveness of narrative therapy in groups on psychological well-being and distress of Iranian women with addicted husbands. Addict Health, 10(1), https://doi.org/1-10. 10.22122/ahj.v10i1.550

Kim J S. (2008). Examining the effectiveness of solution-focused brief therapy: A meta-analysis. $\begin{array}{llll}\text { Research on Social } & \text { Work }\end{array}$ https://doi.org/10.1177/1049731507307807

Kraemer, S., Vetere, E. A., \& Dowling, E. (2005). Narratives of fathers and sons: There is no such thing as a father. Narrative Therapies with Children and their Families: A Practitioners Guide to Concepts and Approaches. Brunner/Routledge.

Legowski, T., \& Brownlee, K. (2001). Working with metaphor in narrative therapy. Journal of Family Psychotherapy, 12(1), 19-28. https://doi.org/10.1300/J085v12n01_02 
Lui, C. (2017). Examining the effectiveness of solution-focused art therapy (SF-AT) for sleep problems of children with traumatic experiences. Doctoral Dissertation, The Ohio State University.

Macdonald, A.J. (2007). Solution-focused therapy: Theory, research \& practice. Sage Publications.

Meydan, B. (2013). Çözüm odaklı kısa süreli psikolojik danışma: Okullardaki etkililiği üzerine bir inceleme. Turkish Psychological Counseling and Guidance Journal, 4(39), 120-129.

Mole, D. W. (2004). How the study and practice of narrative therapy affects the development of therapists and their practices of therapy. Master Thesis, University of Victoria.

Morgan, A. (2002). Beginning to use a narrative approach in therapy. The International Journal of Narrative Therapy and Community Work, (1), 85-90.

Murdock, N. L. (2013). Anlatımsal Terapi (çev. A. Esen Çoban, \& F. Akkoyun). İçinde F: Akkoyun (çev. ed.) Psikolojik danışma ve psikoterapi kuramları: Olgu sunumu yaklaşımıyla (s. 490513). Nobel Yayıncılık.

Payne, M. (2006). Narrative therapy: An introduction for counsellors (2. Edition). Sage Publications.

Russell, S., \& Carey, M. (2002). Re-membering: Responding to commonly asked questions. International Journal of Narrative Therapy \& Community Work, 23(3), 1-13.

Sarıçam, H. (2014). Çözüm odaklı kısa süreli psikolojik danışma süreci. İçinde A. Akın \& Ü. Akın (ed.), Çözüm odaklı kısa süreli grupla psikolojik danışma uygulamaları (ss. 17-34). Nobel Akademi Yayıncılık.

Sklare, G. B. (2013). Çözüm odaklı kısa süreli psikolojik danışma (4. Baskı, çev. D. M. Siyez). Pegem Akademi.

Şahin, F. (2001). Sosyal hizmette güçler perspektifi ve çözüm odaklı mülakat. Aile ve Toplum Eğitim, Kültür ve Araştırma Dergisi, 1(4), 59-72.

Tarragona, M. (2008). Postmodern/poststructuralist therapy. İçinde Twenty-first century psychotherapies: Contemporary approaches to theory and practice (ss. 167-205), J. L. Lebow (Ed). John Wiley \& Sons, Inc.

Uysal, R. (2014a). Çözüm odaklı kısa süreli yaklaşıma dayalı bir müdahale programının ergenlerde risk alma davranışına etkisi [Yayımlanmamış doktora tezi]. Sakarya Üniversitesi.

Uysal, R. (2014b). Çözüm odaklı kısa süreli psikolojik danışma kuramı. İçinde A. Akın \& Ü. Akın (ed.), Çözüm odaklı kısa süreli grupla psikolojik danışma uygulamaları (s. 1-16). Nobel Akademi Yayıncılık.

Vromans, L.P., \& Schweitzer, R.D. (2011). Narrative therapy for adults with majör depressive disorder: Improved symptom and interpersonal outcomes. Psychotherapy Research, 21 (1), 4-15. https://doi.org/10.1080/10503301003591792

Walter, J., \& Peller, J. (1993). Solution-focused brief therapy. The Family Journal, 1(1), 80-81. https://doi.org/10.1177/106648079300100114 
White, M. (1995). Re-authoring Lives: Interviews and essays. Dulwich Centre Publications.

White, M. (2001). Narrative practice and the unpacking of identity conclusions.Gecko: A Journal of Deconstruction and Narrative Ideas in Therapeutic Practice,1, 28-55.

Wolter, J. A., DiLollo, A., \& Apel, K. (2006). A narrative therapy approach to counseling: a model for working with adolescents and adults with language-literacy deficits. Language, Speech, and Hearing Services in Schools, 37, 168-177. https://doi.org/10.1044/0161$1461(2006 / 019)$

Zimmerman, T. S., Jacobsen, R. B., MacIntyre, M., \& Watson, C. (1996). Solution-focused parenting groups: An empirical study.Journal of Systemic Therapies, 15(4), 12-25. https://doi.org/10.1521/jsyt.1996.15.4.12

Zimmerman, T.S., Prest, L.A., \& Wetzel, B.E. (1997). Solution-focused couples therapy groups: An empirical study. Journal of Family Therapy, 19, 125-144. https://doi.org/10.1111/14676427.00044 


\section{EXTENDED ABSTRACT}

\section{Introduction}

Postmodernism and constructivism movements led to the introduction of psychological counseling approaches that emphasize the subjectivity of the experiences in counseling and address the individual with environmental elements such as time zone and locality (Arkonaç, 2008; Karairmak \& Aydın, 2007). Among these approaches, Solution-Focused Brief Counseling and Narrative Counseling are approaches that have been widely used in Turkey and the world in recent years.

\section{Fundamentals of Solution-Focused Brief Counseling and Narrative Counseling Approaches}

Postmodernism drew attention to the importance of focusing on the subjective experiences and the reality of the client in the counseling process rather than the objective reality. Therefore, the experiences of the individual are subjective. Postmodernism emphasizes the positive and strong aspects (such as well-being) of the individual (Karairmak \& Siviş, 2008). The role of the psychological counselor in the counseling process changed and the role of "expert" was replaced by "better listener" (Anderson \& Goolishian, 1992; Murdock, 2013; Payne, 2006; Sklare, 2013; White, 1995). In the psychological counseling process, the client is seen as an "expert". The psychological counselor should be in the "not knowing position" (Anderson \& Goolishian, 1992; Tarragona, 2008).

\section{Counseling Process in Solution-Focused Brief Counseling and Narrative Counseling}

In solution-focused brief counseling, the psychological counselor focuses on the present to understand the problem and the future for solutions. In narrative counseling, the dominant stories originate from the past experiences. When addressing these stories and writing new ones, there is more of a focus on the past and present. In order to understand the client's problem, in the first session of the solution-focused brief counseling, what the client wants to overcome, when and how often the problem is experienced by him/her, and whether the problem changes or not when he/she wants to solve it are examined (Macdonald, 2007). Both at the beginning of the counseling process and at other stages, scaling questions are used to show how intensely the client experiences the problem (De Shazer \& Berg, 1997). In addition, the miracle question is used to understand the client's goals during the counseling process (Iveson, 2002). In this process, the therapy aims the client realize his/her goal with small steps determined by the client himself/herself.

It is important to understand the problem deeply in narrative counseling. Externalizing questions are actively used to get to the bottom of the client's dominant story. These are questions about the name given by the client to the problem (e.g., Sneaky Poo) and what the named problem says to him/her, and at what times it affects him/her more or less (Legowski \& Brownlee, 2001, Mole, 2004; Morgan, 2002; White, 2001). Alternative stories are constructed by rewriting the story instead of the client's problematic dominant story. The alternative stories involve the expectations of the client and the unique outcomes where the effect of the problem is weakest (Carey \& Russell, 2003; White, 1995). Narrative counseling also includes therapeutic practices such as life club, outsider witnesses and definitional ceremony, letters, audio, and video recordings (Murdock, 2013; Russell \& Carey, 2002; White, 1995). 
In solution-focused brief counseling, while taking the client's story, questions are used at the beginning of the session to check the client's current status or to check the effect of homework (De Shazer et al., 2007). In narrative counseling, the reason for asking questions is that the client is the expert of his/her own life and the psychological counselor is the person who tries to learn about the life of the client by asking questions (Corey, 2005; Karairmak \& Bugay, 2010; Morgan, 2002; White, 1995). Externalizing questions allow the problem to be reformed as "something" outside the client and ease the examination of the problem. In the other steps of the counseling process, the counselor's learning process continues with the construction of the client's alternative stories, the assessment of these stories, and various therapeutic practices (Murdock, 2013; Payne, 2006; Wolter, DiLollo, \& Apel, 2006).

The miracle question in solution-focused brief counseling involves describing the desired future and examining the changes that will occur when the problem disappears, and it is one of the most important techniques of this approach (Macdonald, 2007). Questions about exceptional times when the problem does not affect the client's life even for a small moment or affects them less also have an important place in the counseling process (De Shazer et al., 2007). Scaling questions are used to get information about the degree of the problem between before the counseling appointment and the first appointment, where it is now, or where it will be when the miracle happens. Furthermore, scaling is also used in determining the client's goals (De Shazer et al., 2007; Sklare, 2013).

\section{Conclusion}

The studies in which the effectiveness of solution-focused brief counseling and narrative counseling approaches are examined with both qualitative and quantitative methods revealed that there are significant positive changes in many negative experiences (Besa, 1994; Forcht \& Beardslee, 1996; Javanmiri, Kimiaee Abadi, 2012; Zimmerman, Jacobsen, MacIntyre, \& Watson, 1996). In this respect, both approaches are determined to be effective in psychotherapy processes. Both approaches have unique characteristics that set them apart from other approaches. It is believed that the fact that the client is an expert in his/her own life and that his/her phenomena and solutions are important, especially in the relationship between the client and the counselor, have an important contribution to the solution (Corey, 2005; Demirci, 2014; Wolter, DiLollo, \& Apel, 2006). Solution-focused brief counseling has become widespread more rapidly and has been the subject of many studies (Kim, 2008). It is functional especially in terms of use in schools in Turkey (Meydan, 2013). Narrative counseling is a common approach in the world but newly recognized in Turkey (Karairmak \& Bugay, 2010). However, the efforts to increase its recognition have increased in recent years (Çelik, 2017; Dinç \& Dinçer, 2020). 